\title{
Brand loyalty explained by concept recall: recognizing the significance of the brand concept compared to features
}

\author{
Takumi Kato $^{1}$ (D) \\ Revised: 8 March 2021 / Accepted: 31 May 2021 / Published online: 9 June 2021 \\ (c) The Author(s), under exclusive licence to Springer Nature Limited 2021
}

\begin{abstract}
Consumers may be attracted to superficial functionality and design, but they may easily switch brands when another company's product/service with higher functionality and a more fashionable design appears. If consumers remain loyal to a brand, it is because they understand, sympathize with, and value the brand's concept. However, few studies have focused on brand concept as a factor of loyalty. Therefore, this study verified the influence of the brand concept on repurchase intention. Through multiple regression analysis of Apple MacBook Pro, Dyson Big Ball, Nintendo Switch, Facebook, Starbucks, and Tokyo Disney Resort users in Japan, the first hypothesis-consumers who recall a brand concept are more likely to have repurchase intention than those who recall specific features when asked about brand attractiveness-was supported. Furthermore, Fisher's exact test supported a second hypothesis—consumers with high loyalty maintain high-level construal, even if they use a brand frequently and recall the concept as the brand's attractiveness, contrary to construal level theory. By introducing the viewpoint of brand loyalty, the conditions under which construal level theory does not conform were shown. The present study encourages reaffirmation of the importance of brand concept and suggests the concept recall index to effectively use management resources.
\end{abstract}

Keywords Brand management $\cdot$ Loyalty $\cdot$ Concept recall $\cdot$ Pure recall $\cdot$ Construal level theory

\section{Introduction}

With technological advances, product/service functionality often exceeds the standards that consumers require, and they see little difference between brands. This means that competitiveness between brands is shifting to emotional value, such as design, rather than functional value (Noble and Kumar 2008). Although corporate engineers were not previously interested in subjective aesthetics (Adams 2011), the importance of emotional value is now recognized, and companies increasingly focus on design, as demonstrated by the growing number of companies that have chief design officers (Stuhl 2014).

Nevertheless, even when the design is improved, a product/service can seem similar to another from the consumer's point of view, and it can be difficult to improve customers'

Takumi Kato

takumikato@mail.saitama-u.ac.jp

1 Graduate School of Humanities and Social Sciences, Saitama University, 255 Shimo-Okubo, Sakura-ku, Saitama City, Saitama 338-8570, Japan perceptions of value. One reason may be that the brand concept of the product/service is ambiguous and focuses too strongly on design/UX. Consumers may be attracted to superficial functionality and design, but they may easily switch brands when another company's product/service with higher functionality and a more fashionable design appears. If a consumer remains loyal to a brand, it is because they understand, sympathize with, and value the brand's concept (Aaker and Joachimsthaler 2000).

However, while previous brand management studies have clarified factors related to loyalty by assessing features such as product/service performance, quality, and design (Chen 2012; Chiu et al. 2009; Devaraj et al. 2001; Homburg et al. 2015; Hsu et al. 2018; Kumar et al. 2011; Lee et al. 2015; Shen and Yahya 2021; Yeh et al. 2016; Zehir et al. 2011), few studies have focused on the brand concept of a product/ service (hereinafter the brand concept) as a factor of loyalty. Accordingly, the present study hypothesized that consumers who recall a brand concept are more likely to exhibit repurchase intention than consumers who recall specific features, such as attractiveness. In other words, although the importance of brand concept is recognized as a theory of 
business administration and marketing (Gardner and Levy 1955; Lafley and Martin 2013; Park et al. 1991; Simões and Dibb 2001; Stengel et al. 2003; Tilley 1999), to the best of my knowledge, there have been no attempts to demonstrate it as a factor that explains consumer loyalty.

Furthermore, this study also incorporated another theoretical viewpoint of consumer behavior research. According to construal level theory (CLT), when experience with using a product/service increases, the construal level decreases, and it becomes easier to focus on specific rather than essential features (Trope and Liberman 2000). However, previous research on CLT (Hamilton and Thompson 2007; Kim et al. 2008; Liberman et al. 2007; Roehm and Roehm 2011; Trope and Liberman 2000) has not included the perspective of brand loyalty. Thus, few studies have examined the present study's second hypothesis: consumers with high loyalty maintain high-level construal, even though they use the brand frequently and can recall the brand concept as a feature of its attractiveness.

Although the importance of brand concept has been widely asserted in academic research on business administration and marketing, effects specifically related to brand concept have not been quantitatively evaluated. Thus, the present study encourages reaffirmation of the importance of brand concept and applies the concept of recall index to effectively use the means of design and UX for building strong brands.

\section{Literature review}

Brand concept refers to brand-unique abstract meanings that typically originate from a firm's efforts to differentiate itself from its competitors (Park et al. 1991). A brand concept defines the value provided to customers and should meet consumers' needs (Park et al. 1986). The framework of a brand concept comprises the target (who), value and positioning (what), and execution method (how; Lafley and Martin 2013; Stengel et al. 2003). For example, Starbucks describes its concept as the "third place" (Schultz 1997; Starbucks 2020), for which the "who" would be consumers looking for a place to relax when they go out, the "what" is a place outside of home or work where people can spend relaxing time alone or gather for a sense of community, and the "how" is by providing an atmosphere that incorporates aspects such as earth tones, comfortable music, and coffee.

Brand image refers to consumers' cultivated perceptions of products and advertisements that are developed based on concepts devised by marketers (Zenker 2014). Further, consumers will develop attitudes toward a brand through their experience with its products/services and advertising, and an image will be formed as brand knowledge (Campbell and Keller 2003; Hoeffler and Keller 2003). Therefore, the brand concept is the root of a product/service, and consumers form a brand image and gain knowledge by experiencing the value created by this concept.

The brand concept is the criterion for decision-making in all corporate activities, such as planning, development, production, and sales (Simões and Dibb 2001; Tilley 1999). Product/service development involves many day-to-day decisions made by various departments, and consistent standards need to be applied throughout the process. If a concept is ambiguous, it cannot be effectively applied, and the product/service's purpose devolves to following trends already seen in the industry. Consistent target embodiment can be thought of in three ways: zero moment of truth when viewing a website, first moment of truth when viewing a product in the store, and second moment of truth when using a product (Lecinksi 2011). Branding helps consumers distinguish products/services from one another; if consumers value a brand's meaning, they will be more loyal to it. Therefore, for a product/service to become a strong brand, it is necessary to clearly define the concept before it enters the market and maintain the concept and embodiment perceived by the consumer over its life (Gardner and Levy 1955).

In addition, the concept plays a large role in expanding a brand or forming brand alliances. The factor that distinguishes the success or failure of a brand extension is consistency within categories and concepts (Jin and Zou 2013; Lanseng and Olsen 2012; Park et al. 1991; Punyatoya 2014; Thorbjørnsen 2005). Consumers who exhibit high loyalty also have high demands for consistency (Samuelsen et al. 2015), and the consistency of a concept is more important than its category. For instance, Breitling for Bentley, a co-brand of Swiss mechanical watchmaker Breitling and Bentley's venerable luxury car in the UK, has a low degree of product category matching but a high reputation for its expressive concept matching (Lanseng and Olsen 2012).

Brand loyalty factors are generally explained by product/service features, such as performance (Kumar et al. 2011; Yeh et al. 2016), quality (Devaraj et al. 2001; Shen and Yahya 2021; Zehir et al. 2011), design (Homburg et al. 2015; Hsu et al. 2018), and UX/usability (Chen 2012; Chiu et al. 2009; Lee et al. 2015). Recently, more specific emotional elements, such as brand colors (Jin et al. 2019) and product sounds (Kato et al. 2020) have been studied. Alternatively, studies incorporating factor evaluation based on brand image (Unal and Aydin 2013), brand reputation (Han et al. 2021; Selnes 1993), brand trust (Chaudhuri and Holbrook 2001; Lau and Lee 1999), and word of mouth (Eelen et al. 2017; Liang et al. 2018; Podoshen 2006) are common. Thus, although many loyalty factors have been reported in academic research on marketing, there are few examples of research where brand concept has been explored as a loyalty factor. Previous research has proposed methods for understanding brand concept from the consumer's point of view; 
however, brand concept has not been evaluated as a loyalty factor (John et al. 2006; Schnittka et al. 2012). In addition, some research has divided concepts into general categories (e.g., functional, symbolic, luxurious; Bhat and Reddy 1998; Hagtvedt and Patrick 2009; Park et al. 1986; Topaloglu and Gokalp 2018), making it difficult to determine if these methods pinpoint whether consumers understand brand concepts, as the general categories are too broad.

Hence, compared to product/service features, there has been little evaluation of consumer loyalty as it relates to brand concept. There are three possible reasons for this. First, researchers and corporate marketers believe it is difficult for consumers to evaluate concepts that cannot be directly experienced. Second, many brand concepts are ambiguous, and marketers can lose sight of their purpose because they cannot clearly identify how their products/services are meaningful to customers (Blount and Leinwand 2019). When the concept is ambiguous, products/services rely on trendy, superficial designs and advanced functions, and it is difficult to evaluate the brand concept. Consistency is the most important factor in strengthening a brand, and the meaning (or concept) of the underlying brand is necessary to maintain consistency over a long period of time (Keller 2019). Third, even if there is a clear concept, there may not be a consistent embodiment of the product/service, and it could come across as ambiguous in the marketplace. It takes significant effort to consistently embody a concept without compromise when each corporate department makes different claims; therefore, a thoroughly implemented product/ service is a rare entity that can grow into a strong brand (Gardner and Levy 1955; Park et al. 1986). In fact, companies with strong product/service brands have development processes that enhances the degree of perfection by embodying many prototypes based on the concept and testing them many times (Keller and Kotler 2009).

Consumers may be attracted to superficial functionality and design, but they may easily switch brands when another company's product/service with higher functionality and a more fashionable design appears. If a consumer remains loyal to a brand, it is because they understand, sympathize with, and value the brand's concept (Aaker and Joachimsthaler 2000). Hence, whether consumers recall the brand concept when asked about the attractiveness of the brand greatly influences their loyalty. Therefore, when asked about the attractiveness of a brand, consumers should be able to recall the keywords in its concept. If the focus is on a product/service with a clear concept that builds a strong brand in the market, evaluation should be possible. Therefore, the following hypothesis was derived:

H1: Consumers who recall the brand concept are more likely to have a repurchase intention than consumers who recall specific features, such as its attractiveness.
However, this hypothesis is contrary to CLT. Psychological distance includes temporal, spatial, social, and empirical distance (Liberman et al. 2007). When there is great psychological distance between the consumer and object, the construal level is high, and the consumer grasps the essential attributes of the object. In contrast, when there is a small psychological distance between the consumer and the object, the construal level is low, and the consumer concretely grasps the object (Trope and Liberman 2000). A study of hotel review sites reported that essential attributes were more important when temporal and social distances were great (Kim et al. 2008). In a study of banks, fit with personal values was effective for long-term campaigns, and a specific amount of money was effective for shortterm campaigns (Roehm and Roehm 2011). As experience with using a product/service increases, the psychological distance decreases, and the construal level becomes lower. In experiments on music player devices, consumers had a lower construal level when directly touching the product, and emphasis was placed on ease of use rather than product desirability (Hamilton and Thompson 2007). However, this study lacked a perspective on brand loyalty. There is a clear difference between consumers who use a product/service due to inertia and those who use it because of an attachment, even if both groups use it with the same frequency (Dick and Basu 1994). Therefore, as shown in Fig. 1, two hypotheses were derived:

H2-1: Consumers with low loyalty have low-level construal when they use a brand frequently, and recall specific features, such as function and design, as the attractiveness of the brand (consistent with CLT).

H2-2: Consumers with high loyalty maintain high-level construal, even if they use a brand frequently, and recall the concept as the attractiveness of the brand (contrary to CLT).

\section{Research method}

\section{Survey method}

This study verified the three hypotheses with the target product brands of Apple MacBook Pro (hereafter, Apple), Dyson Big Ball (canister vacuum cleaner, hereafter, Dyson), and Nintendo Switch (hereafter, Nintendo), and target service brands Facebook, Starbucks, and Tokyo Disney Resort (hereafter, Disney). These brands were selected for two reasons: confirmation of the concept on the corporate website and covering diverse B2C industries. An online survey was conducted in Japan from November 5 to 10 2020. Inclusion criteria for respondents were that they (a) were aged between 20 and 59 years; (b) had purchased new products from three 
Fig. 1 Visual depiction of $\mathrm{H} 2$ (left side: construal-level theory, right side: hypothesis in this study)

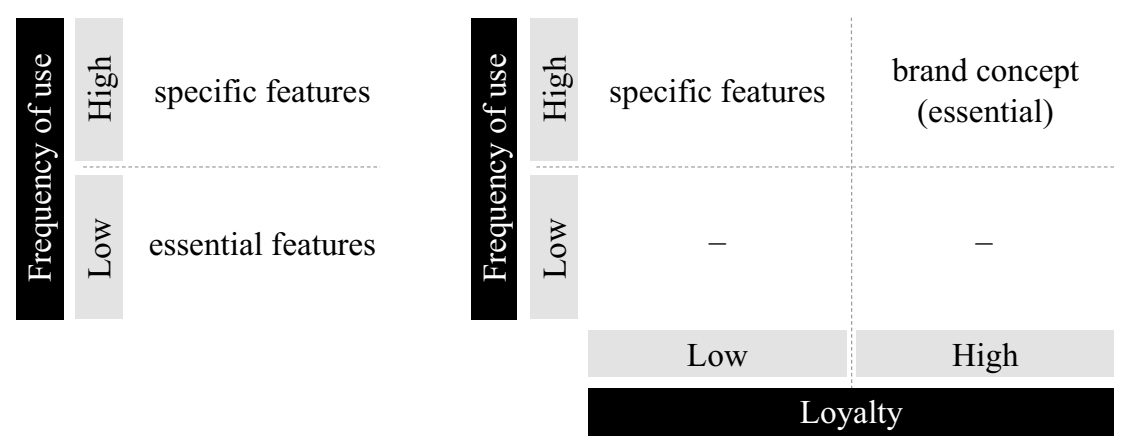

of the target brands; and (c) used the target brand at least once a month (for Disney, at least once every three years).

The survey was randomly distributed through a survey panel owned by a major Japanese research company, Cross Marketing, Inc. The survey consisted of a screening survey and a main survey, both conducted online. The screening survey identified respondents who met criteria (a)-(c). Those who met these criteria were immediately routed to the main survey. The screening survey comprised eight questions: (1) gender, (2) age, (3) area of residence, (4) occupation, (5) annual household income, (6) ownership of each product brand, (7) how the product brand was purchased, and (8) frequency of use of the brand. When the criteria were met for multiple brands in (6)-(8), the respondent was randomly assigned to one brand and directed to the main survey. The results of the survey collection were as follows: of 41,077 screening survey respondents, 40,139 completed it; of these, 2953 responded to the main survey, and 2897 completed it. Next, 400 respondents for each brand were randomly sampled for a total of 2400 respondents. The sample sizes were evenly distributed for each brand for two reasons: first, to ensure bias-free evaluation; and second to ensure that the number of concepts recalled could be easily compared. The distribution is shown in Table 1.

Table 1 Variable list and statistics

\begin{tabular}{|c|c|c|c|c|c|}
\hline Item & Content & $\begin{array}{l}\text { Number of } \\
\text { respondents }\end{array}$ & Item & Content & $\begin{array}{l}\text { Number of } \\
\text { respondents }\end{array}$ \\
\hline \multirow[t]{6}{*}{ Brand } & Apple MacBook Pro & 400 & \multirow[t]{10}{*}{ Job } & Management & 86 \\
\hline & Dyson big ball & 400 & & Marketing & 278 \\
\hline & Nintendo switch & 400 & & Engineer & 299 \\
\hline & Facebook & 400 & & Back office & 276 \\
\hline & Starbucks & 400 & & Professional & 145 \\
\hline & Disney & 400 & & Freelance & 102 \\
\hline \multirow[t]{2}{*}{ Gender } & Male & 1227 & & Part-time & 315 \\
\hline & Female & 1173 & & Homemaker & 343 \\
\hline \multirow[t]{4}{*}{ Age } & $20 \mathrm{~s}$ & 621 & & Student & 101 \\
\hline & $30 \mathrm{~s}$ & 627 & & Unemployed & 455 \\
\hline & $40 \mathrm{~s}$ & 592 & \multirow[t]{5}{*}{ Household Income } & $<4$ million yen & 495 \\
\hline & $50 \mathrm{~s}$ & 560 & & 4 to 6 million yen & 599 \\
\hline \multirow[t]{8}{*}{ Area } & Hokkaido & 113 & & 6 to 8 million yen & 509 \\
\hline & Tohoku & 117 & & 8 to 10 million yen & 332 \\
\hline & Hokuriku & 128 & & 10 million to 15 million yen & 465 \\
\hline & Kanto & 1181 & \multirow[t]{5}{*}{ Frequency (Disney) } & Five to seven times a week (once a week) & 756 \\
\hline & Tokai & 217 & & Two to four times a week (once a month) & 424 \\
\hline & Kinki & 361 & & Once a week (once every six months) & 424 \\
\hline & Chugoku & 141 & & Once every two weeks (once a year) & 359 \\
\hline & Kyusyu & 142 & & Once a month (once every $2-3$ years) & 437 \\
\hline
\end{tabular}


In the main survey, respondents were asked about one assigned brand. The questionnaire items were as follows: (9) satisfaction, (10) recommendation intention, (11) repurchase intention (product)/reuse intention (service; hereinafter, repurchase intention), (12) reason for repurchase intention. Items (9)-(11) were rated on a 7-point Likert scale ( $1=$ very unsatisfied to $7=$ very satisfied $)$. The mean values (satisfaction, recommendation intention, repurchase intention) for the brands were as follows: Apple (5.688, 5.523, 5.713), Dyson (4.895, 4.743, 4.535), Nintendo (5.640, 5.445, 4.313), Facebook (4.490, 4.298, 4.810), Starbucks (5.458, $5.415,5.858)$, and Disney (5.580, 5.650, 5.888). Item (12) was a pure recall question, in which an answer was freely requested without presenting options to the respondent. This was because aided recall, which presents options, introduces bias, and the options may then be overestimated (Kardes et al. 2002). There was concern that the concept of interest in this study would encourage consumers who were not normally aware of it to recognize it. By using pure recall, respondents could provide answers about a brand concept only if they really understood it.

\section{Verification method}

It should be noted that, to date, there is no established brand concept framework or evaluation method. In this study, the focus was on whether consumers could recall the concept when asked about the attractiveness of a brand. Furthermore, to avoid introducing bias, no options were presented and the answer was to be provided by pure recall. Therefore, consumer responses were evaluated based on whether they included keywords from the concepts published by each brand.

The concepts for each brand as extracted from their official websites were as follows: Apple, "the ultimate work tool for professionals who innovate in the world" (Apple 2020); Dyson, "the cleaner that doesn't lose suction" (Dyson 2000); Nintendo, "transforming from home console to portable system in a snap" and "controllers give you total gameplay flexibility" (Nintendo 2020); Facebook, "give people the power to build community and bring the world closer together" (Facebook 2020); Starbucks, "third place" (Schultz 1997; Starbucks 2020); and Disney, "the kingdom of dreams and magic" (Oriental Land Co. 2020). Note that Oriental Land Co. operates Tokyo Disney Resort under a license agreement with the Walt Disney Company.

The present study used natural language processing to determine whether respondents provided keywords used in the brand concepts as their stated reasons for repurchase intention. Words (nouns and adjectives) of interest were extracted from the sentences freely written by the respondents, and when they were used in a positive sense, an appearance flag called a "tag" was added. As shown in Table 2, the concept tags for each brand were set, and the keywords were registered in the database. To eliminate subjectivity, the keywords for each brand were set to three (nouns and adjectives). For instance, Disney's concept C6_Disney includes the words "dream," "magic," and "magical;" however, differences in notations with exactly the same meaning were taken into consideration. In the Japanese language, there are four ways to express an idea: kanji, hiragana, katakana, and English. For example, the word cute, “可愛い,”“かわいい,” “カワイイ,” [kawaii] and “キュート” [kjú:t] have the same meaning. In addition, it is necessary to understand specific features, such as function and design, as comparison targets. In natural language processing, there are no established standard tags; thus, the researchers defined the tags, and as the words contained in data differ, it was necessary to define the tags that matched the data. In this study, features that appeared more than 20 times in total were extracted and used as tags. Therefore, four tags were set as emotional values: design, convenience, fun, and delicious. Functional values were set as: function, quality, information, and lineup. Direct negative expressions, such as failure, heavy, expensive, coronavirus, "I already have it (hence, no repurchase intention)," and "nothing special," were also set.

Nouns and adjectives were extracted by morphological analysis; when registered words were detected, parsing defined whether a word was stated positively. If it was positive, the corresponding tag was added. If a word belonging to the same tag was detected multiple times in one text, the corresponding tag was only added once. Japanese opensource software MeCab was used for morphological analysis and CaboCha was used for parsing. There were 1988 tags from the 2400 respondents, and 729 respondents were not tagged. The distribution of tags is shown in Table 2. For example, for the C1_Apple tag, 34 out of 400 people mention the concept. The percentage of people who mentioned the concept (concept recall rate) was highest for Disney, at $28.5 \%$, and lowest for Nintendo, at $6.75 \%$. Note that some texts mentioned words registered as Apple's concept in other brands, but this study dealt only with the concept of specific brands. Then, as shown in Table 3, the respondent attributes and tags were made into dummy variables, and the subsequent analysis was conducted.

H1 was verified by multiple regression analysis in which the objective variable was repurchase intention (No. 1 in Table 3), the control variables were the attribute dummies obtained in the screening survey (No. 4-33), and the explanatory variables were the tag dummies (No. 34-48). Note that when 2400 (number of respondents) is multiplied by the mean of the tag dummies in Table 3, this equals the total number in Table 2. The concept was that only tags that match each brand are handled; thus, the total is 428 . Since there were many variables, the stepwise method was adopted: estimate the regression equation that incorporates 


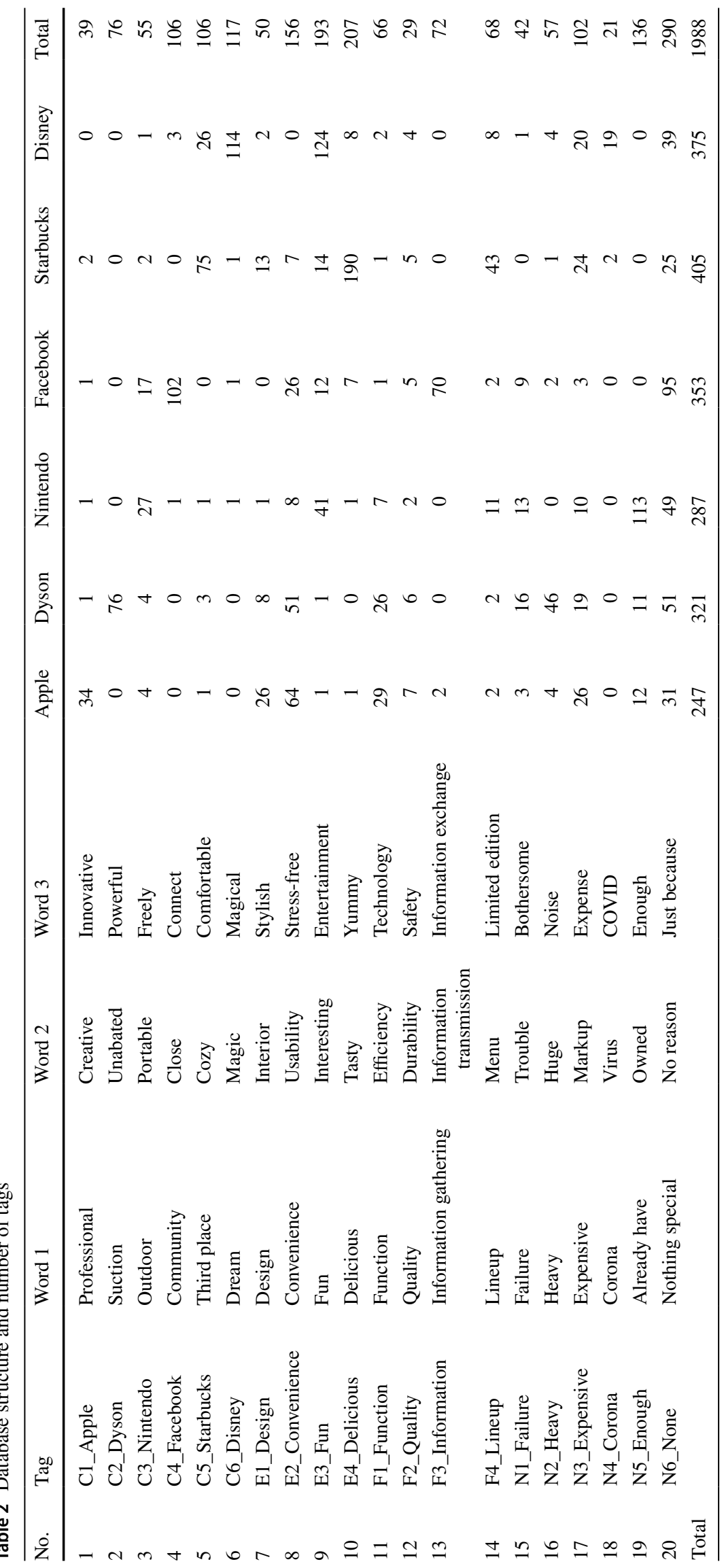

张 
Table 3 Variable list and statistics

\begin{tabular}{|c|c|c|c|c|c|}
\hline No. & Variable & Description & Breakdown & Mean & SD \\
\hline 1 & Satisfaction & Satisfaction & 7-Point scale & 5.292 & 1.330 \\
\hline 2 & Recommendation & Recommendation intention & 7-Point scale & 5.179 & 1.322 \\
\hline 3 & Repurchase & Repurchase intention & 7-Point scale & 5.186 & 1.472 \\
\hline 4 & Apple & Dummy variable of brands & Apple & 0.167 & 0.373 \\
\hline 5 & Dyson & (Criteria: Nintendo) & Dyson & 0.167 & 0.373 \\
\hline 6 & Facebook & & Facebook & 0.167 & 0.373 \\
\hline 7 & Starbucks & & Starbucks & 0.167 & 0.373 \\
\hline 8 & Disney & & Disney & 0.167 & 0.373 \\
\hline 9 & Female & Dummy variable for gender & Female & 0.489 & 0.500 \\
\hline 10 & Age_20s & Dummy variable for age & $20 \mathrm{~s}$ & 0.259 & 0.438 \\
\hline 11 & Age_30s & (Criteria: 50s) & $30 \mathrm{~s}$ & 0.261 & 0.439 \\
\hline 12 & Age_40s & & $40 \mathrm{~s}$ & 0.247 & 0.431 \\
\hline 13 & Area_02_Tohoku & Dummy variable for residential areas & Tohoku & 0.049 & 0.215 \\
\hline 14 & Area_03_Hokuriku & (Criteria: Hokkaido) & Kanto & 0.053 & 0.225 \\
\hline 15 & Area_04_Kanto & & Chubu & 0.492 & 0.500 \\
\hline 16 & Area_05_Tokai & & Kansai & 0.090 & 0.287 \\
\hline 17 & Area_06_Kinki & & Chugoku & 0.150 & 0.358 \\
\hline 18 & Area_07_Chugoku & & Shikoku & 0.059 & 0.235 \\
\hline 19 & Area_08_Kyusyu & & Kyusyu & 0.059 & 0.236 \\
\hline 20 & Job_01_Management & Dummy variable for jobs & Management & 0.036 & 0.186 \\
\hline 21 & Job_02_SalesMarketing & (Criteria: unemployed) & Marketing & 0.116 & 0.320 \\
\hline 22 & Job_03_Engineer & & Engineer & 0.125 & 0.330 \\
\hline 23 & Job_04_BackOffice & & Back Office & 0.115 & 0.319 \\
\hline 24 & Job_05_Profession & & Profession & 0.060 & 0.238 \\
\hline 25 & Job_06_Freelancer & & Freelance & 0.043 & 0.202 \\
\hline 26 & Job_07_Parttimer & & Part-time & 0.131 & 0.338 \\
\hline 27 & Job_08_Homemaker & & Homemaker & 0.143 & 0.350 \\
\hline 28 & Job_09_Student & & Student & 0.042 & 0.201 \\
\hline 29 & Income_600 & Dummy variable for household income & 4 to 6 million yen & 0.250 & 0.433 \\
\hline 30 & Income_800 & (Criteria: less than four million yen) & 6 to 8 million yen & 0.212 & 0.409 \\
\hline 31 & Income_1000 & & 8 to 10 million yen & 0.138 & 0.345 \\
\hline 32 & Income_1500 & & 10 million to 15 million yen & 0.194 & 0.395 \\
\hline 33 & Frequency & Dummy variable for frequency of use & $\begin{array}{l}\text { Five to seven times a week } \\
\text { (Disney: once a week) }\end{array}$ & 0.315 & 0.465 \\
\hline 34 & Concept & Dummy variable for tags & Concept & 0.178 & 0.383 \\
\hline 35 & E1_Design & & E1_Design & 0.021 & 0.143 \\
\hline 36 & E2_Convenience & & E2_Convenience & 0.065 & 0.247 \\
\hline 37 & E3_Fun & & E3_Fun & 0.080 & 0.272 \\
\hline 38 & E4_Delicious & & E4_Delicious & 0.086 & 0.281 \\
\hline 39 & F1_Function & & F1_Function & 0.028 & 0.164 \\
\hline 40 & F2_Quality & & F2_Quality & 0.012 & 0.109 \\
\hline 41 & F3_Informative & & F3_Informative & 0.030 & 0.171 \\
\hline 42 & F4_Lineup & & F4_Lineup & 0.028 & 0.166 \\
\hline 43 & N1_Failure & & N1_Failure & 0.018 & 0.131 \\
\hline 44 & N2_Heavy & & N2_Heavy & 0.024 & 0.152 \\
\hline 45 & N3_Expensive & & N3_Expensive & 0.043 & 0.202 \\
\hline 46 & N4_Corona & & N4_Corona & 0.009 & 0.093 \\
\hline 47 & N5_Enough & & N5_Enough & 0.058 & 0.234 \\
\hline 48 & N6_None & & N6_None & 0.121 & 0.326 \\
\hline
\end{tabular}

$S D$ standard deviation 
all the variables and remove the variables to improve Akaike's information criterion (AIC). Then, when the AIC ceases to improve, the model is finalized. H1 was tested by a model for all brands to reach generalized conclusions. In addition, models for each brand were built for consideration.

H2-1 and H2-2 were verified by propensity score matching (Rosenbaum and Rubin 1983), a typical method for estimating causal effects when random allocation designs for treatment are difficult. Consumer attribute variables were aggregated into one variable called the propensity score, and variables other than the presence or absence of treatment were homogenized. Here, as shown in Table 1, 756 people who selected the highest frequency, "five to seven times a week" (for Disney, once a week), for question (8) were defined as the treatment group (frequent users) and 1644 others were defined as the control group (non-frequent users). Since the characteristics of consumers with high frequency of use and those with low frequency of use differed, the causal effect was estimated by matching subjects with close propensity scores and homogenizing both groups. When the true value of the propensity score of each subject is unknown, estimating from the data by a logistic regression model is common.

First, loyalty was extracted by factor analysis from the three variables of satisfaction, recommendation intention, and repurchase intention (No. 1-3 in Table 3), and the factor scores of each respondent were calculated. The factor scores ranged from -3.3 to 1.4 , and 539 respondents with 0.7 or higher, who corresponded to approximately the top $20 \%$, were defined as high loyalty and 1861 as low loyalty. From the concept (No. 34) and the specific feature (No. 35-42) in the answers to question (12), respondents were categorized into one of the recall categories: neither (None), only the specific feature (Feature), only the concept (Concept), or both (Both).

Next, as shown Table 4, each respondent's propensity score was estimated by a logistic regression model in which the treatment group dummy (No. 33 in Table 3) was used as the objective variable and the respondent attributes and brand dummy variables (No. 4-32) were used as the explanatory variables. The stepwise method was applied to variable selection. Then, the respondents with similar propensity scores were matched. Extraction was found to be non-restoring. As a result, out of 539 high-loyalty respondents (treatment group: 192; control group: 347), a total of 192 (96 in each group) were extracted. As shown in Table 5, the respondent attributes of both groups are homogenized. Similarly, of the 1,861 low-loyalty respondents (treatment group: 564, control group: 1,297), a total of 964 (i.e., 482 in each group) were extracted.

Finally, a matrix of group $\times$ recall category was created for both high- and low-loyalty respondents, and the presence or absence of a significant difference was verified by Fisher's exact test. The analysis environment was R, and the step AIC function from the MASS package for multiple regression analysis and the Match function from the Matching package for propensity score matching were used.
Table 4 Logistic regression model for estimating propensity score

\begin{tabular}{|c|c|c|c|c|c|c|}
\hline \multirow[t]{2}{*}{ Variable } & \multicolumn{3}{|c|}{ Low Loyalty } & \multicolumn{3}{|c|}{ High Loyalty } \\
\hline & Odds ratio & SE & $p$-value & Odds ratio & SE & $p$-value \\
\hline (Intercept) & 0.696 & 0.083 & $0.000 * * *$ & 0.690 & 0.280 & 0.186 \\
\hline Group_Apple & 2.714 & 0.150 & $0.000 * * *$ & 4.928 & 0.331 & $0.000 * * *$ \\
\hline Group_Dyson & 0.388 & 0.151 & $0.000 * * *$ & 0.572 & 0.381 & 0.143 \\
\hline Group_Facebook & & & & 3.008 & 0.590 & 0.062 \\
\hline Group_Starbucks & 0.076 & 0.276 & $0.000 * * *$ & 0.052 & 0.491 & $0.00 * * * 0$ \\
\hline Group_Disney & 0.041 & 0.391 & $0.000 * * *$ & 0.022 & 0.570 & $0.000 * * *$ \\
\hline Female & & & & 1.258 & 0.269 & 0.393 \\
\hline Job_01_Management & & & & 0.865 & 0.576 & 0.802 \\
\hline Job_02_SalesMarketing & 0.773 & 0.189 & 0.172 & & & \\
\hline Job_06_Freelancer & & & & 2.829 & 0.726 & 0.152 \\
\hline Job_08_Homemaker & 1.382 & 0.162 & $0.046^{*}$ & & & \\
\hline Income_1500 & & & & 3.447 & 0.348 & $0.000 * * *$ \\
\hline McFadden & 0.195 & & & 0.443 & & \\
\hline Adj. McFadden & 0.188 & & & 0.411 & & \\
\hline c-statistics & 0.781 & & & 0.910 & & \\
\hline
\end{tabular}

$S E$ standard error

$* * * p<0.001 ; * * p<0.01 ; * p<0.05$ 
Table 5 Propensity score matching results for high-loyalty respondents

\begin{tabular}{|c|c|c|c|c|c|}
\hline \multirow[t]{2}{*}{ Variable } & \multicolumn{2}{|c|}{ Low frequency } & \multicolumn{2}{|c|}{ High frequency } & \multirow[t]{2}{*}{ SMD } \\
\hline & Mean & SD & Mean & SD & \\
\hline Group_Apple & 0.240 & 0.429 & 0.250 & 0.435 & 0.024 \\
\hline Group_Dyson & 0.167 & 0.375 & 0.156 & 0.365 & 0.028 \\
\hline Group_Facebook & 0.052 & 0.223 & 0.094 & 0.293 & 0.160 \\
\hline Group_Starbucks & 0.063 & 0.243 & 0.063 & 0.243 & 0.000 \\
\hline Group_Disney & 0.042 & 0.201 & 0.042 & 0.201 & 0.000 \\
\hline Female & 0.438 & 0.499 & 0.479 & 0.502 & 0.083 \\
\hline Age_20s & 0.292 & 0.457 & 0.292 & 0.457 & 0.000 \\
\hline Age_30s & 0.323 & 0.470 & 0.240 & 0.429 & 0.185 \\
\hline Age_40s & 0.198 & 0.401 & 0.281 & 0.452 & 0.195 \\
\hline Area_02_Tohoku & 0.042 & 0.201 & 0.031 & 0.175 & 0.055 \\
\hline Area_03_Hokuriku & 0.052 & 0.223 & 0.031 & 0.175 & 0.104 \\
\hline Area_04_Kanto & 0.354 & 0.481 & 0.510 & 0.503 & 0.318 \\
\hline Area_05_Tokai & 0.219 & 0.416 & 0.073 & 0.261 & 0.420 \\
\hline Area_06_Kinki & 0.156 & 0.365 & 0.167 & 0.375 & 0.028 \\
\hline Area_07_Chugoku & 0.083 & 0.278 & 0.073 & 0.261 & 0.039 \\
\hline Area_08_Kyusyu & 0.073 & 0.261 & 0.031 & 0.175 & 0.187 \\
\hline Job_01_Management & 0.073 & 0.261 & 0.063 & 0.243 & 0.041 \\
\hline Job_02_SalesMarketing & 0.125 & 0.332 & 0.125 & 0.332 & 0.000 \\
\hline Job_03_Engineer & 0.146 & 0.355 & 0.115 & 0.320 & 0.092 \\
\hline Job_04_BackOffice & 0.083 & 0.278 & 0.115 & 0.320 & 0.104 \\
\hline Job_05_Profession & 0.052 & 0.223 & 0.042 & 0.201 & 0.049 \\
\hline Job_06_Freelancer & 0.010 & 0.102 & 0.010 & 0.102 & 0.000 \\
\hline Job_07_Parttimer & 0.073 & 0.261 & 0.115 & 0.320 & 0.143 \\
\hline Job_08_Homemaker & 0.146 & 0.355 & 0.167 & 0.375 & 0.057 \\
\hline Job_09_Student & 0.031 & 0.175 & 0.031 & 0.175 & 0.000 \\
\hline Income_600 & 0.260 & 0.441 & 0.260 & 0.441 & 0.000 \\
\hline Income_800 & 0.208 & 0.408 & 0.208 & 0.408 & 0.000 \\
\hline Income_1000 & 0.115 & 0.320 & 0.104 & 0.307 & 0.033 \\
\hline Income_1500 & 0.219 & 0.416 & 0.177 & 0.384 & 0.104 \\
\hline
\end{tabular}

$S D$ standard deviation, $S M D$ standardized mean difference

\section{Results and discussion}

As shown in Table 6, when examining the results of the whole model estimated by multiple regression analysis, the tag E1_Design, at 0.681, was the highest among specific features. This finding was in line with previous studies that have reported the importance of emotional value as represented by design is increasing (Adams 2011; Noble and Kumar 2008; Sweeney and Soutar 2001). However, Concept at 0.710 contributed more than the specific characteristics of emotional value and functional value among the regression coefficients that were significant at the $5 \%$ level. Hence, H1 was supported.

In reviewing the results of each brand, Apple had the highest Concept at 0.934, followed by E1_Design at 0.889 and F2_Quality at 0.745 . Negative effects extracted for Apple included N2_Heavy, which was very large at -3.207, N3_Expensive-0.756, and N6_None-0.858. In terms of respondent attributes, the characteristics of high frequency of use, profession (e.g., designer), and male gender tended to be associated with high repurchase intention. The following four brands showed the same tendencies as Apple. Dyson: F1_Function 0.925, E1_Design $0.804<$ Concept 1.013; Nintendo: E3_Fun $1.012<$ Concept 1.755; Starbucks: F4_Lineup 0.313, E4_Delicious $0.295<$ Concept 0.472 ; and Disney: E3_Fun 0.104, E4_ Delicious $-0.233<$ Concept 0.563 . Five out of six brands were suitable, which was considered significant for the usefulness of concept recall. Only Facebook exhibited factors that were more effective than the concept confirmed; Concept $0.458<$ E2_Convenience 0.770 . This was likely because, as Facebook was the only brand in the study that can be used free of charge, the psychological barrier to reuse was low; thus, the factor that can be experienced more directly is prioritized. The business model of services provided free of charge is more peculiar than that of paid services (Hamari et al. 2020).

From another perspective, it was confirmed that individual brands have unique characteristics. Since E4_Delicious had a negative effect on Disney, this indicates that consumers seeking delicious food are less likely to have high repurchase intention. The tag N4_Corona was extracted for Disney as a negative effect. The COVID-19 pandemic has made it difficult for consumers who are concerned about infection to visit crowded places, such as theme parks. Consumers have been shown to behave in a risk-averse manner in a pandemic situation, especially in the tourism industry (Schiopu et al. 2021), which has been reportedly the most affected by business closures (Gursoy and Chi 2020). This was in line with the results obtained in this study. Since N5_Enough was extracted for Dyson and Nintendo, this indicated that a certain number of consumers have difficulty answering when asked about their next purchase intention, as they already have the product. As a job, Job_06_Freelancer in Starbucks became significant. As shown in the concept of the "third place" (Schultz 1997; Starbucks 2020), the place (in-store space) is vital. Therefore, with the growth of the gig economy, space at Starbucks is often also used as a workplace. In addition to the physical elements of WiFi and comfortable chairs, seeing other people working is reported to be stimulating, and moderate noise can enhance creativity (Mehta et al. 2012). This tendency was further strengthened by the increase in working remotely during the COVID-19 pandemic. In fact, in 2020, a Starbucks store designed as a "teleworking branch" for businesspeople opened in Ginza, Tokyo (Baseel 2020). However, Job_09_Student had a negative effect on Starbucks. Students find Starbucks to be expensive, and it is presumed that freelancers use the store as a workspace. 


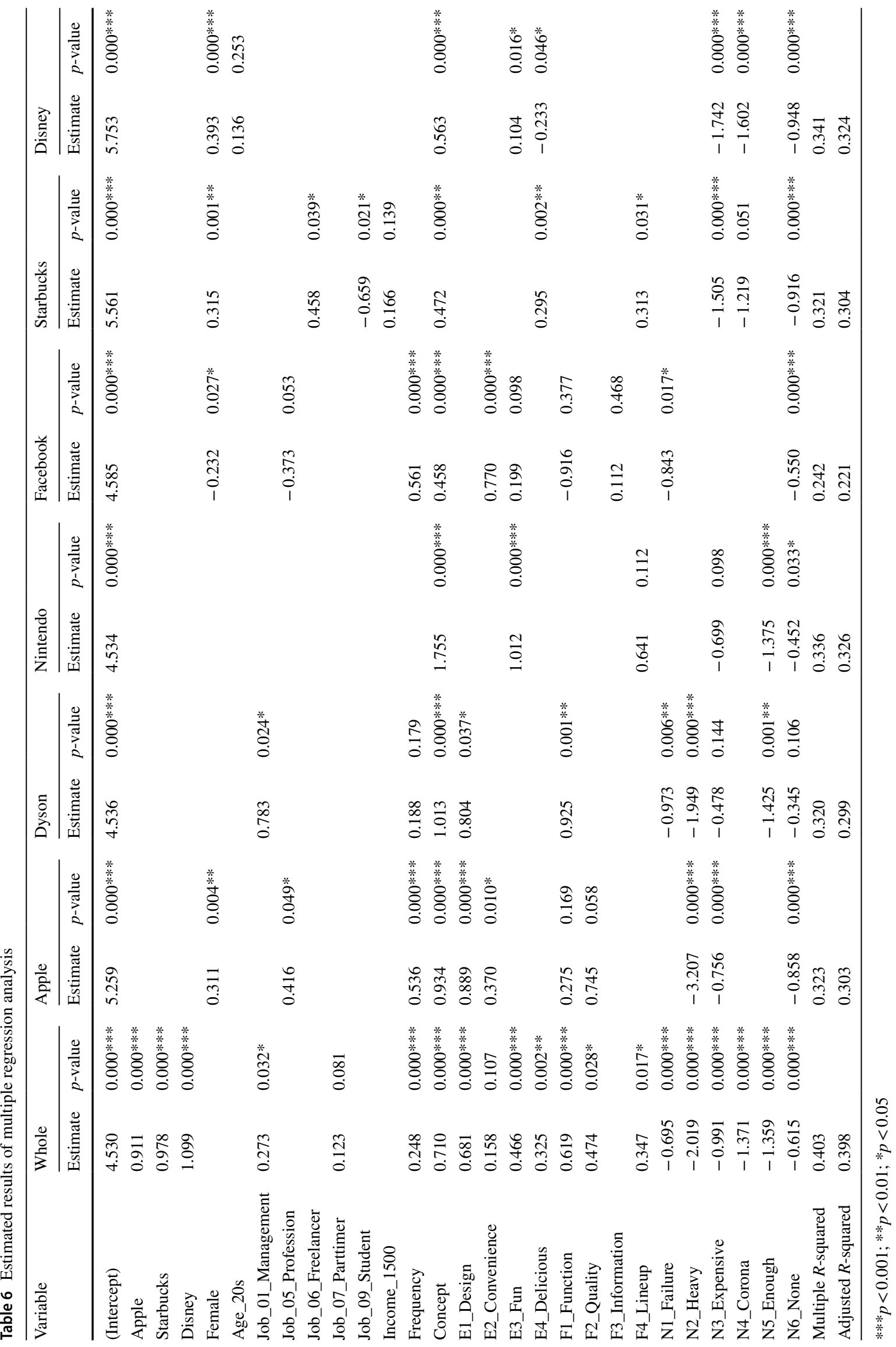

然 
Next, the results for $\mathrm{H} 2-1$ and $\mathrm{H} 2-2$ were evaluated. As shown at the top of Table 7, at low loyalty, there was no significant difference in distribution between the lowfrequency-use control group and the high-frequency-use treatment group. The results of Fisher's exact test found the $p$-value $=0.180$, and no significant differences were confirmed. Meanwhile, in high loyalty, the ratio of the control group recalling brand concept was $13.5 \%$, while that of the treatment group was $29.2 \%$, and the feature decreased from 31.3 to $21.9 \%$. The results of Fisher's exact test found the $p$-value $=0.032$, and it a significant difference was confirmed. From the above, although H2-1 was not supported, H2-2 was supported. Therefore, it can be concluded that, contrary to CLT, consumers with high loyalty maintain high-level construal, even if they use a brand frequently, and recall the concept as the attractiveness of products/services. In this way, it is the contribution of this study to introduce consumer loyalty as a new perspective to the concept of CLT and clarify the conditions of consumer behavior that do not match CLT. Furthermore, this study showed different results from CLT even in consumers with low loyalty. According to previous research on CLT (Hamilton and Thompson 2007; Kim et al. 2008; Roehm and Roehm 2011), the closer the psychological distance, the more the consumer's interest shifts to specific rather than essential features. However, in this study, for consumers with low loyalty, there was no difference in the factors recalled as the attractiveness of the brand depending on the psychological distance measured by frequency of use. The reason was assumed that the definition of essential features was different. In previous studies, the core functions of the target products/services were defined as essential features. Thus, CLT did not address brand concept, unlike the present study. The verification of CLT from the viewpoint of brand concept is a novel feature of this study, and since there is limited knowledge in this area, further research is required.

Regarding implications for practice, first, companies should reaffirm the importance of brand concept. In this study, the effect of the concept was quantitatively shown in comparison with concrete features such as design. This makes it possible to more clearly understand the importance of concepts that were previously recognized as a theory of business administration and marketing (Gardner and Levy 1955; Lafley and Martin 2013; Park et al. 1991; Simões and
Dibb 2001; Stengel et al. 2003; Tilley 1999). In a company, many departments and professionals are involved in developing and delivering products and services. If each department passes a judgment for varying purposes simultaneously, the focus will be blurred and products similar to that of other companies will be produced. The brand concept plays a major role here. In order for the concept to take root in the organization, it is important to present the basis for quantitatively showing its superiority as in this study. Second, the index of concept recall-a unique index proposed by this study-should be emphasized in brand management. In general, after measuring loyalty based on aspects such as recommendation intention and repurchase intention, efforts are made to understand the factors that contribute to loyalty by evaluating each specific feature of a product/service brand. While this study's results certainly showed positive effects regarding design and performance, consumers who are attracted to superficial functionality and design may easily switch brands when a different company's product offers higher functionality and a more fashionable design. In contrast, consumers who understand, sympathize with, and value a brand's concept display stronger brand loyalty. Therefore, companies should evaluate whether consumers recall the concept as their reason for remaining loyal to a brand. It is hoped that the index of concept recall will be adopted not only in the industrial world but also in the academic world in research on consumer behavior and brand management.

\section{Conclusion}

In this study, hypotheses regarding concept recall were tested to identify the factors related to brand loyalty. The hypothesis that consumers who recall a brand concept are more likely to have repurchase intention than those who recall specific features (e.g., design) when asked about the attractiveness of a brand was supported. In addition, CLT argues that the more experience a consumer has with a product, the lower the construal level, and consumer interest shifts to specific rather than essential features. However, CLT does not include loyalty. Therefore, the present study supported its hypothesis contrary to CLT, that consumers with high loyalty maintain high-level construal, even if they
Table 7 Results of Fisher's exact test

\begin{tabular}{llllllll}
\hline Loyalty & Frequency & None & Feature & Concept & Both & Total & $p$-value \\
\hline \multirow{2}{*}{ Low } & Low (control) & $335(69.5 \%)$ & $80(16.6 \%)$ & $47(9.8 \%)$ & $20(4.1 \%)$ & 482 & 0.180 \\
& High (treatment) & $303(62.9 \%)$ & $95(19.7 \%)$ & $57(11.8 \%)$ & $27(5.6 \%)$ & 482 & \\
\multirow{2}{*}{ High } & Low (control) & $48(50.0 \%)$ & $30(31.3 \%)$ & $13(13.5 \%)$ & $5(5.2 \%)$ & 96 & $0.032 *$ \\
& High (treatment) & $39(40.6 \%)$ & $21(21.9 \%)$ & $28(29.2 \%)$ & $8(8.3 \%)$ & 96 & \\
\hline
\end{tabular}

$* * * p<0.001 ; * * p<0.01 ; * p<0.05$ 
use the brand frequently and recall the concept as the attractiveness of the product/service. Thus, when consumers are asked about the attractiveness of the brand, ability to recall the concept strongly influences loyalty.

There are three main limitations to the present study. First, generalization is limited, as only six target products/ services were examined. In the future, it will be necessary to expand the target industries and number of brands. Second, the results may vary depending on the concept evaluation method. In this study, arbitrariness was eliminated as much as possible by extracting and using three keywords (nouns and adjectives) from the concept texts published by each company. However, results may vary slightly depending on the number of keywords and survey method (e.g., pure recall vs. aided recall). Third, since pure recall was applied, features that consumers usually have difficulty recalling are unlikely to appear in the evaluation (e.g., corporate social responsibility). Therefore, only typical features, such as design, convenience, function, and quality, were compared in this study. Thus, further research is required on these issues.

\section{Appendix}

See Table 8.

Table 8 Questionnaire details

\begin{tabular}{|c|c|c|c|}
\hline No. & Question & Answer type & Option \\
\hline 1 & Please choose your gender & Single answer & Male, female, other \\
\hline 2 & Please select your age & Single answer & $20 \mathrm{~s}, 30 \mathrm{~s}, 40 \mathrm{~s}, 50 \mathrm{~s}$, other \\
\hline 3 & Please select your area of residence & Single answer & $\begin{array}{l}\text { Hokkaido, Tohoku, Hokuriku, Kanto, Tokai, Kinki, Chu- } \\
\text { goku, Kyusyu }\end{array}$ \\
\hline 4 & Please select your occupation & Single answer & $\begin{array}{l}\text { Management, marketing, engineer, back office, profession, } \\
\text { freelance, part-time, homemaker, student, unemployed }\end{array}$ \\
\hline 5 & Please select your annual household income & Single answer & $\begin{array}{l}\text { Less than } 4 \text { million yen, } 4 \text { to } 6 \text { million yen, } 6 \text { to } 8 \text { million } \\
\text { yen, } 8 \text { to } 10 \text { million yen, } 10 \text { million to } 15 \text { million yen, } \\
\text { More than } 15 \text { million yen }\end{array}$ \\
\hline 6 & Please select the ownership of [target brand] & Single answer & Own, not own \\
\hline 7 & $\begin{array}{l}\text { Please select the purchase method of [target brand] you } \\
\text { are using }\end{array}$ & Single answer & New, used \\
\hline 8 & Please select how often you use [target brand] & Single answer & $\begin{array}{l}\text { Five to seven times a week, two to four times a week, once } \\
\text { a week, once every two weeks, once a month (as shown } \\
\text { in Table 1, only disney has different options) }\end{array}$ \\
\hline 9 & How satisfied are you with the [target brand]? & 7-Point Likert scale & 1: very unsatisfied, 7 : very satisfied \\
\hline 10 & $\begin{array}{l}\text { How much would you recommend [target brand] to your } \\
\text { family and friends? }\end{array}$ & 7-Point Likert scale & $\begin{array}{l}\text { 1: I would not recommend at all, 7: I would definitely } \\
\text { recommend }\end{array}$ \\
\hline 11 & $\begin{array}{l}\text { Would you like to repurchase/reuse the [target brand] } \\
\text { again the next time you purchase a product/use a ser- } \\
\text { vice in the [applicable category]? }\end{array}$ & 7-Point Likert scale & $\begin{array}{l}\text { 1: I would not repurchase/reuse at all, 7: I would definitely } \\
\text { repurchase/reuse very much }\end{array}$ \\
\hline 12 & Please specify the reason for answering No. 11 & Pure recall & - \\
\hline
\end{tabular}


Funding This work was supported by JSPS KAKENHI Grant Number JP20K22115.

\section{Declarations}

Conflict of interest The corresponding author states that there is no conflict of interest.

\section{References}

Aaker, D.A., and E. Joachimsthaler. 2000. Brand leadership. New York: The Free Press.

Adams, J. 2011. Good products, bad products: Essential elements to achieving superior quality. New York: McGraw-Hill Education.

Apple. 2020. MacBook Pro. Apple. https://www.apple.com/jp/macbo ok-pro-16/, accessed 1 April 2020.

Baseel, C. 2020. Starbucks opens teleworking branch in Tokyo's Ginza. Japan Today. August 14, https://japantoday.com/category/busin ess/starbucks-opens-teleworking-branch-in-tokyo\%E2\%80\%99sginza, accessed 1 April 2020.

Blount, S., and P. Leinwand. 2019. Why are we here? Harvard Business Review 97 (6): 132-139.

Bhat, S., and S.K. Reddy. 1998. Symbolic and functional positioning of brands. Journal of Consumer Marketing 15 (1): 32-43.

Campbell, M.C., and K.L. Keller. 2003. Brand familiarity and advertising repetition effects. Journal of Consumer Research 30 (2): 292-304.

Chaudhuri, A., and M.B. Holbrook. 2001. The chain of effects from brand trust and brand affect to brand performance: The role of brand loyalty. Journal of Marketing 65 (2): 81-93.

Chen, Y.Y. 2012. Why do consumers go internet shopping again? Understanding the antecedents of repurchase intention. Journal of Organizational Computing and Electronic Commerce 22 (1): $38-63$.

Chiu, C.M., C.C. Chang, H.L. Cheng, and Y.H. Fang. 2009. Determinants of customer repurchase intention in online shopping. Online Information Review 33 (4): 761-784.

Devaraj, S., K.F. Matta, and E. Conlon. 2001. Product and service quality: The antecedents of customer loyalty in the automotive industry. Production and Operations Management 10 (4): 424-439.

Dick, A.S., and K. Basu. 1994. Customer loyalty: Toward an integrated conceptual framework. Journal of the Academy of Marketing Science 22 (2): 99-113.

Dyson, J. 2000. Against the odds: An autobiography. Knutsford: Texere.

Eelen, J., P. Özturan, and P.W. Verlegh. 2017. The differential impact of brand loyalty on traditional and online word of mouth: The moderating roles of self-brand connection and the desire to help the brand. International Journal of Research in Marketing 34 (4): 872-891.

Facebook. 2020 Our mission. Facebook. https://about.fb.com/compa ny-info/, accessed 1 April 2020.

Gardner, B.B., and S.J. Levy. 1955. The product and the brand. Harvard Business Review 33 (2): 33-39.

Gursoy, D., and C.G. Chi. 2020. Effects of COVID-19 pandemic on hospitality industry: Review of the current situations and a research agenda. Journal of Hospitality Marketing \& Management 29 (5): 527-529.

Hagtvedt, H., and V.M. Patrick. 2009. The broad embrace of luxury: Hedonic potential as a driver of brand extendibility. Journal of Consumer Psychology 19 (4): 608-618.
Han, S.H., C.H.S. Chen, and T.J. Lee. 2021. The interaction between individual cultural values and the cognitive and social processes of global restaurant brand equity. International Journal of Hospitality Management 94: 102847.

Hamari, J., N. Hanner, and J. Koivisto. 2020. "Why pay premium in freemium services?" A study on perceived value, continued use and purchase intentions in free-to-play games. International Journal of Information Management 51: 102040.

Hamilton, R.W., and D.V. Thompson. 2007. Is there a substitute for direct experience? Comparing consumers' preferences after direct and indirect product experiences. Journal of Consumer Research 34 (4): 546-555.

Hoeffler, S., and K.L. Keller. 2003. The marketing advantages of strong brands. Journal of Brand Management 10 (6): 421-445.

Homburg, C., M. Schwemmle, and C. Kuehnl. 2015. New product design: Concept, measurement, and consequences. Journal of Marketing 79 (3): 41-56.

Hsu, C.L., Y.C. Chen, T.N. Yang, W.K. Lin, and Y.H. Liu. 2018. Does product design matter? Exploring its influences in consumers' psychological responses and brand loyalty. Information Technology \& People 31 (3): 886-907.

Jin, C., M. Yoon, and J. Lee. 2019. The influence of brand color identity on brand association and loyalty. Journal of Product \& Brand Management 21 (1): 50-62.

Jin, L., and D. Zou. 2013. Extend to online or offline? The effects of web-brand extension mode, similarity, and brand concept on consumer evaluation. Journal of Marketing Management 29 (7-8): 755-771.

John, D.R., B. Loken, K. Kim, and A.B. Monga. 2006. Brand concept maps: A methodology for identifying brand association networks. Journal of Marketing Research 43 (4): 549-563.

Kato, T., R. Yokote, T. Kondo, and K. Konishi. 2020. Effect of products' startup sound on repurchase intention. International Journal of Japan Association for Management Systems 12 (1): 81-86.

Kardes, F.R., D.M. Sanbonmatsu, M.L. Cronley, and D.C. Houghton. 2002. Consideration set overvaluation: When impossibly favorable ratings of a set of brands are observed. Journal of Consumer Psychology 12 (4): 353-361.

Keller, K.L. 2019. Strategic brand management: Building, measuring, and managing brand equity. London: Pearson Education Limited.

Keller, K.L., and P. Kotler. 2009. Marketing management. Hoboken: Pearson Prentice Hall.

Kim, K., M. Zhang, and X. Li. 2008. Effects of temporal and social distance on consumer evaluations. Journal of Consumer Research 35 (4): 706-713.

Kumar, V., L. Batista, and R. Maull. 2011. The impact of operations performance on customer loyalty. Service Science 3 (2): 158-171.

Lafley, A.G., and R.L. Martin. 2013. Playing to win: How strategy really works. Brighton: Harvard Business Press.

Lanseng, E., and L.E. Olsen. 2012. Brand alliances: The role of brand concept consistency. European Journal of Marketing 46 (9): $1108-1126$.

Lau, G.T., and S.H. Lee. 1999. Consumers' trust in a brand and the link to brand loyalty. Journal of Market-Focused Management 4 (4): 341-370.

Lecinksi, J. 2011. Winning the zero moment of truth. Think with Google. https://www.thinkwithgoogle.com/future-of-marketing/ emerging-technology/2011-winning-zmot-ebook/, accessed 1 April 2020.

Lee, D., J. Moon, Y.J. Kim, and Y.Y. Mun. 2015. Antecedents and consequences of mobile phone usability: Linking simplicity and interactivity to satisfaction, trust, and brand loyalty. Information \& Management 52 (3): 295-304.

Liang, L.J., H.C. Choi, and M. Joppe. 2018. Understanding repurchase intention of Airbnb consumers: Perceived authenticity, electronic 
word-of-mouth, and price sensitivity. Journal of Travel \& Tourism Marketing 35 (1): 73-89.

Liberman, N., Y. Trope, and C. Wakslak. 2007. Construal level theory and consumer behavior. Journal of Consumer Psychology 17 (2): 113-117.

Mehta, R., R. Zhu, and A. Cheema. 2012. Is noise always bad? Exploring the effects of ambient noise on creative cognition. Journal of Consumer Research 39 (4): 784-799.

Nintendo. 2020. Nintendo switch. https://www.nintendo.com/switch/ system/, accessed 1 April 2020.

Noble, C.H., and M. Kumar. 2008. Using product design strategically to create deeper consumer connections. Business Horizons 51 (5): $441-450$

Oriental Land Co. 2020. Tokyo Disneyland. Facility Overview. OLC Group. http://www.olc.co.jp/en/tdr/profile.html, accessed 1 April 2020.

Park, C.W., B.J. Jaworski, and D.J. MacInnis. 1986. Strategic brand concept-image management. Journal of Marketing 50 (4): 135-145.

Park, C.W., S. Milberg, and R. Lawson. 1991. Evaluation of brand extensions: The role of product feature similarity and brand concept consistency. Journal of Consumer Research 18 (2): 185-193.

Podoshen, J.S. 2006. Word of mouth, brand loyalty, acculturation and the American Jewish consumer. Journal of Consumer Marketing 23 (5): 266-282.

Punyatoya, P. 2014. Evaluation of branding strategies for global versus local brand: The role of concept consistency. International Journal of Business Excellence 7 (1): 112-128.

Roehm, M.L., and H.A. Roehm Jr. 2011. The influence of redemption time frame on responses to incentives. Journal of the Academy of Marketing Science 39 (3): 363-375.

Rosenbaum, P.R., and D.B. Rubin. 1983. The central role of the propensity score in observational studies for causal effects. Biometrika 70 (1): 41-55.

Samuelsen, B.M., L.E. Olsen, and K.L. Keller. 2015. The multiple roles of fit between brand alliance partners in alliance attitude formation. Marketing Letters 26 (4): 619-629.

Schiopu, A.F., R.I. Hornoiu, M.A. Padurean, and A.M. Nica. 2021. Virus tinged? Exploring the facets of virtual reality use in tourism as a result of the COVID-19 pandemic. Telematics and Informatics 60: 101575.

Schnittka, O., H. Sattler, and S. Zenker. 2012. Advanced brand concept maps: A new approach for evaluating the favorability of brand association networks. International Journal of Research in Marketing 29 (3): 265-274.

Schultz, H. 1997. Pour your heart into it: How Starbucks built a company one cup at a time. Santa Clara: Hyperion.

Selnes, F. 1993. An examination of the effect of product performance on brand reputation, satisfaction and loyalty. European Journal of Marketing 27 (9): 19-35.

Shen, C., and Y. Yahya. 2021. The impact of service quality and price on passengers' loyalty towards low-cost airlines: The Southeast Asia perspective. Journal of Air Transport Management 91: 101966

Simões, C., and S. Dibb. 2001. Rethinking the brand concept: New brand orientation. Corporate Communications: An International Journal 6 (4): 217-224.
Starbucks. 2020. Starbucks principles for upholding the third place: For our partners, our customers and our communities. https:// www.starbucks.com/responsibility/learn-more/policies/thirdplace, accessed 1 April 2020.

Stengel, J.R., A.L. Dixon, and C.T. Allen. 2003. Listening begins at home. Harvard Business Review 81 (11): 106-117.

Stuhl, M. 2014. What is behind the rise of the chief design officer? Forbes, November 11, https://www.forbes.com/sites/groupthink/ 2014/11/11/what-is-behind-the-rise-of-the-chief-design-officer/? $\mathrm{sh}=48 \mathrm{fc} 0 \mathrm{e} 433 \mathrm{c} 25$, accessed 1 April 2020.

Sweeney, J.C., and G.N. Soutar. 2001. Consumer perceived value: The development of a multiple item scale. Journal of Retailing 77 (2): 203-220.

Thorbjørnsen, H. 2005. Brand extensions: Brand concept congruency and feedback effects revisited. Journal of Product and Brand Management 14 (4): 250-257.

Tilley, C. 1999. Built-in branding: How to engineer a leadership brand. Journal of Marketing Management 15 (1-3): 181-191.

Topaloglu, O., and O.N. Gokalp. 2018. How brand concept affects consumer response to product recalls: A longitudinal study in the U.S. auto industry. Journal of Business Research 88: 245-254.

Trope, Y., and N. Liberman. 2000. Temporal construal and timedependent changes in preference. Journal of Personality and Social Psychology 79 (6): 876-889.

Unal, S., and H. Aydın. 2013. An investigation on the evaluation of the factors affecting brand love. Procedia Social and Behavioral Sciences 92: 76-85.

Yeh, C.H., Y.S. Wang, and K. Yieh. 2016. Predicting smartphone brand loyalty: Consumer value and consumer-brand identification perspectives. International Journal of Information Management 36 (3): 245-257.

Zehir, C., A. Şahin, H. Kitapçı, and M. Özşahin. 2011. The effects of brand communication and service quality in building brand loyalty through brand trust; the empirical research on global brands. Procedia Social and Behavioral Sciences 24: 1218-1231.

Zenker, S. 2014. Measuring place brand equity with the advanced Brand Concept Map (aBCM) method. Place Branding and Public Diplomacy 10 (2): 158-166.

Publisher's Note Springer Nature remains neutral with regard to jurisdictional claims in published maps and institutional affiliations.

Takumi Kato is currently Assistant Professor at Graduate School of Humanities and Social Sciences, Saitama University, Japan. He obtained his Ph.D. in Business Administration and Master of Business Administration from Graduate School of Business Sciences from University of Tsukuba, and Bachelor of Science Degree from Keio University, Tokyo, Japan. He joined Mitsubishi Electric Corporation in 2012. In 2014, he joined Honda Motor Co Ltd., and was chief analyst of the Business Analytics Division. His role was product planning and brand management. In 2015, he joined Saitama University. His research interests include marketing, marketing research, consumer behavior, and brand management. 